\title{
Characteristics of cadmium uptake and membrane transport in roots of intact wheat (Triticum aestivum L.) seedlings ${ }^{\text {is }}$
}

\author{
Lian-Zhen Li ${ }^{a}$, Chen Tu ${ }^{\text {a }}$, Willie J.G.M. Peijnenburg ${ }^{\text {b, c }}$, Yong-Ming Luo ${ }^{\text {a, * }}$ \\ ${ }^{a}$ Key Laboratory of Coastal Zone Environmental Processes and Ecological Remediation, Yantai Institute of Coastal Zone Research (YIC), Chinese Academy of \\ Sciences (CAS), Shandong Provincial Key Laboratory of Coastal Zone Environmental Processes, YICCAS, Yantai, PR China \\ ${ }^{\mathrm{b}}$ National Institute of Public Health and the Environment, Center for Safety of Substances and Products, P.O. Box 1, 3720 BA Bilthoven, The Netherlands \\ ${ }^{\mathrm{c}}$ Institute of Environmental Sciences (CML), Leiden University, Leiden, The Netherlands
}

\section{A R T I C L E I N F O}

\section{Article history:}

Received 12 July 2016

Received in revised form

16 November 2016

Accepted 30 November 2016

Available online 21 December 2016

\section{Keywords:}

$\mathrm{Ca}^{2+}$ channel

Cadmium

$\mathrm{K}^{+}$channel

Scanning ion-selective electrode technique

Wheat (Triticum aestivum L.)

Uptake mechanisms

\begin{abstract}
A B S T R A C T
Wheat is one of several cereals that is capable of accumulating higher amounts of $\mathrm{Cd}$ in plant tissues. It is important to understand the $\mathrm{Cd}^{2+}$ transport processes in roots that result in excess Cd accumulation. Traditional destructive technologies have limited capabilities in analyzing root samples due to methodological limitations, and sometimes may result in false conclusions. The mechanisms of $\mathrm{Cd}^{2+}$ uptake into the roots of wheat seedlings (Triticum aestivum L.) were investigated by assessing the impact of various inhibitors and channel blockers on $\mathrm{Cd}$ accumulation as well as the real-time net $\mathrm{Cd}^{2+}$ flux at roots with the non-destructive scanning ion-selective electrode technique. The P-type ATPase inhibitor $\mathrm{Na}_{3} \mathrm{VO}_{4}(500 \mu \mathrm{M})$ had little effect on Cd uptake $(p<0.05)$ and the kinetics of transport in the root of wheat, suggesting that $\mathrm{Cd}^{2+}$ uptake into wheat root cells is not directly dependent on $\mathrm{H}^{+}$gradients. While, the uncoupler 2,4-dinitrophenol significantly limited $\mathrm{Cd}^{2+}$ uptake $(p<0.05)$ and transport kinetics in the root of wheat, suggesting the existence of metabolic mediation in the $\mathrm{Cd}^{2+}$ uptake process by wheat. The $\mathrm{Cd}$ content at the whole-plant level in wheat was significantly $(p<0.05)$ decreased upon pretreatment with the $\mathrm{Ca}^{2+}$ channel blockers $\mathrm{La}^{3+}$ or $\mathrm{Gd}^{3+}$ and Verapamil, but not in case of pretreatment with the $\mathrm{K}^{+}$channel blocker tetraethylammonium (TEA). In addition, the inhibitors of the $\mathrm{Ca}^{2+}$ channel, as well as high concentrations of $\mathrm{Ca}^{2+}$, reduced the real-time net $\mathrm{Cd}^{2+}$ fluxes at the root surface in SIET experiments. These results indicate that $\mathrm{Cd}^{2+}$ moves across the plasma lemma of the wheat root via $\mathrm{Ca}^{2+}$ channels. In addition, our results suggested a role for protein synthesis in mediating $\mathrm{Cd}^{2+}$ uptake and transport by wheat.
\end{abstract}

() 2016 Published by Elsevier Ltd.

\section{Introduction}

Cadmium $\left(\mathrm{Cd}^{2+}\right)$ is a highly toxic trace element that is present in all soils. Due to high Cd mobility and bioavailability in the soil-plant system it can easily enter the food chain, representing a potential health risk. As compared with other cereals, wheat (Triticum aestivum $\mathrm{L}$.) tends to accumulate more $\mathrm{Cd}$ in plant tissues when grown in soils that contain elevated levels of this toxic metal (Hart et al., 1998; Puschenreiter et al., 2005). A maximum permissible concentration of $\mathrm{Cd}$ in wheat grain has been set by national and international health authorities in response to the potential health

\footnotetext{
This paper has been recommended for acceptance by Prof. W. Wen-Xiong.

* Corresponding author. No. 17, Chunhui Road, Yantai 264003, PR China.

E-mail addresses: lianzhen.li@yic.ac.cn (L.-Z. Li), ctu@yic.ac.cn (C. Tu), Willie. Peijnenburg@rivm.nl (W.J.G.M. Peijnenburg), ymluo@yic.ac.cn (Y.-M. Luo).
}

risks of Cd accumulation (FAO/WHO, 2001; European Commission, 2001; GB 2762, 2012; Australia New Zealand. Standard 1.4.1, 2013).

To allow for control of Cd uptake in this crop species it is important to understand the physiological and biological processes that result in excess $\mathrm{Cd}$ accumulation. To identify possible pathways for $\mathrm{Cd}^{2+}$ uptake, the uptake and transport of $\mathrm{Cd}^{2+}$ at the root surface has been extensively characterized in wheat (Hart et al., 1998). Due to the relatively poor spatial and temporal resolution of traditional techniques, most reports have failed to identify the underlying uptake mechanisms involved (Newman, 2001). Measurement of specific ion fluxes using ion-selective microelectrodes has contributed significantly to the identification and functional characterization of the transporter (Newman et al., 1987; Shabala et al., 1997; Smith et al., 1994; Kochian et al., 1992; Pineros et al., 1998). The ion-selective microelectrode technique to measure specific ion fluxes non-invasively is ideally suited for this purpose, 
given its key features of e.g. being non-invasive and displaying high spatial and temporal resolution (Newman, 2001).

As a non-essential element for plants, Cd has been assumed to be taken up by transporters for essential elements as a consequence of lack of specificity of the transporters (Pence et al., 2000; Cohen et al., 1998; Connolly et al., 2002). Potassium and calcium are the very important inorganic macronutrients of the living cell. Numerous reports have focused on the alleviation of Cd phytotoxicity and accumulation by Ca and K (Suzuki, 2005; Ismail, 2008; Zorrig et al., 2012). Nevertheless, the underlying mechanism of effects of essential elements on $\mathrm{Cd}^{2+}$ toxicity and accumulation is still unclear, although some hypothetical mechanisms to interpret the interactions of $\mathrm{Ca}^{2+}$ or $\mathrm{K}^{+}$with $\mathrm{Cd}^{2+}$ (Kinraide, 1998; Yang and Juang, 2015; Liu et al., 2014) have been proposed. There is little direct evidence in support of the possibility of uptake of $\mathrm{Cd}^{2+}$ by channels that are permeable to $\mathrm{Ca}^{2+}$ or $\mathrm{K}^{+}$in wheat root. Thus, the present study was designed to determine the specificity of the $\mathrm{Cd}$ transport system by examining the effect of pharmaceuticals as well as of $\mathrm{Ca}$ or $\mathrm{K}$ on Cd uptake and real-time $\mathrm{Cd}^{2+}$ fluxes at the roots of intact wheat seedlings with the application of nondestructive scanning ion-selective electrode technique.

For this purpose, we measured the Cd content in whole wheat seedlings with pre-treatment of a range of pharmaceuticals (including a metabolic inhibitor and ion channel blockers) as well as in the presence of cations. To verify the uptake and transport mechanisms thus identified, we also monitored the real-time net $\mathrm{Cd}^{2+}$ fluxes at the root surface using the scanning ion-selective electrode technique (SIET). By assessing the effects of the metabolic inhibitor dinitrophenol (DNP) and the $\mathrm{H}^{+}$-ATPase inhibitor $\mathrm{Na}_{3} \mathrm{VO}_{4}$ on $\mathrm{Cd}$ accumulation or real-time net $\mathrm{Cd}^{2+}$ fluxes at the root, we investigated if $\mathrm{Cd}^{2+}$ uptake and transport were dependent on metabolic energy or on $\mathrm{H}^{+}$-gradients. To test whether $\mathrm{Ca}^{2+}$ and $\mathrm{K}^{+}$ channels are involved in the membrane transport system of wheat, or whether other transport mechanisms occur, we measured the $\mathrm{Cd}$ content in the plants. Thereupon, we determined the real-time net $\mathrm{Cd}^{2+}$ fluxes at the roots in the presence and absence of $\mathrm{Ca}^{2+}$ and $\mathrm{K}^{+}$, as well as with treatment of $\mathrm{Ca}^{2+}\left(\mathrm{La}^{3+}, \mathrm{Gd}^{3+}\right.$ or Verapamil $)$ and $\mathrm{K}^{+}$ (tetraethylammonium, TEA) channels blockers. In addition, the potential role of phytochelatin (PC) and protein synthesis on $\mathrm{Cd}$ uptake by wheat (Triticum aestivum $\mathrm{L}$.) was evaluated by blocking PCs and protein production via L-Buthionine-sulfoximine (BSO) and cycloheximide (CHX), respectively.

\section{Materials and methods}

\subsection{Plant material culture}

To investigate possible $\mathrm{Cd}^{2+}$ uptake pathways into wheat root, bread wheat (Triticum aestivum L.) variety Jimai 22 , which has been widely planted in northern China, was used in this study. Plants of wheat were grown as described elsewhere (Hart et al., 1998). In brief, seeds were surface sterilized and germinated on sterile filter paper. Germinated seedlings were transferred to black polyethylene cups positioned in light-sealed black $5 \mathrm{~L}$ polyethylene pots containing continuously aerated Hoagland solution $(\mathrm{pH}$ at $6.0 \pm 0.2$ ) that was replaced once every two days. Seedlings were grown for 8 days in a climate-controlled room at $25{ }^{\circ} \mathrm{C}$ and $18{ }^{\circ} \mathrm{C}$ during $16 / 8 \mathrm{~h}$ light/dark, and healthy plant seedlings of uniform size were selected for the subsequent experiments.

\subsection{Cd accumulation upon treatment of metabolic inhibitors and $P C$ and protein synthesis inhibitors}

The inhibitors were mixed with the Hoagland solution to achieve their following final concentrations: DNP, $50 \mu \mathrm{M} ; \mathrm{Na}_{3} \mathrm{VO}_{4}$,
$500 \mu \mathrm{M}$; BSO, $250 \mu \mathrm{M}$; CHX, $20 \mu \mathrm{M}$. These concentrations were based on results of previous literature reports demonstrating they are physiologically relevant (Pang et al., 2006; Zhang et al., 2012; Zeng et al., 2009).

The seedlings were pre-treated with solutions containing the pharmacological agents ( $\mathrm{pH}$ 6.0) for $12 \mathrm{~h}$ before the uptake experiment. Pre-treatment in pharmacological free solution was used as the control treatment. After pre-exposure, the seedlings were rinsed twice and then were transferred to Hoagland solutions containing $10 \mu \mathrm{M} \mathrm{Cd}$ in $1 \mathrm{~L}$ HDPE containers. One seedling was transplanted into each container. There were four containers for each treatment as replicates. Plants were harvested after $7 \mathrm{~d}$, washed in $1.0 \mathrm{mM}$ EDTA, rinsed with deionized water, oven-dried, weighed and digested with $\mathrm{HNO}_{3}$. Cd concentrations in the digest were determined by ICP-MS (Agilent 7500i, Agilent Technologies Co. Ltd, USA). GBW07605 tea leaves (State Bureau of Technical Supervision, People's Republic of China) were used as certified reference materials for quality control of $\mathrm{Cd}$ determination. Measured concentrations agreed well with the certified concentrations for Cd.

\subsection{Effect of ions and ion channel blockers on uptake of Cd}

In order to investigate the effect of Ca and $\mathrm{K}$ channel blockers on Cd uptake by Triticum aestivum L., an uptake experiment was conducted similarly as described above. The seedlings were preexposed in solutions containing $1 \mathrm{mM} \mathrm{LaCl}, 100 \mu \mathrm{M} \mathrm{GdCl}$, $50 \mu \mathrm{M}$ Verapamil or $100 \mu \mathrm{M}$ TEA for $12 \mathrm{~h}$ prior to the uptake experiment. The experimental procedure used was the same as described above.

To further test if $\mathrm{Ca}$ and $\mathrm{K}$ channels or other ion channels were involved in $\mathrm{Cd}^{2+}$ transport in the plasma membrane, an experiment was conducted to assess the effect of exogenous ions including $\mathrm{Ca}$, $\mathrm{Mg}$, Na and $\mathrm{K}$ on $\mathrm{Cd}$ uptake by Triticum aestivum L.. Intact seedlings of Triticum aestivum L. were treated with $10 \mu \mathrm{M} \mathrm{Cd}$, and with different concentrations of $\mathrm{Ca}^{2+}, \mathrm{Mg}^{2+}, \mathrm{Na}^{+}$and $\mathrm{K}^{+}$respectively in Hoagland nutrient solution. $\mathrm{CaCl}_{2}$ or $\mathrm{MgSO}_{4}$ was added to the background solution to provide three test solutions of $0.1,1.0$, and $10 \mathrm{mM}$ of $\mathrm{Ca}$ or $\mathrm{Mg}$ (Ca or $\mathrm{Mg}$-set), while $\mathrm{NaCl}$ or $\mathrm{KCl}$ was added to the background solution to provide three test solutions of 2.5, 5.0, and $10.0 \mathrm{mM}$ Na or $\mathrm{K}$ ( $\mathrm{Na}$ or K-set).

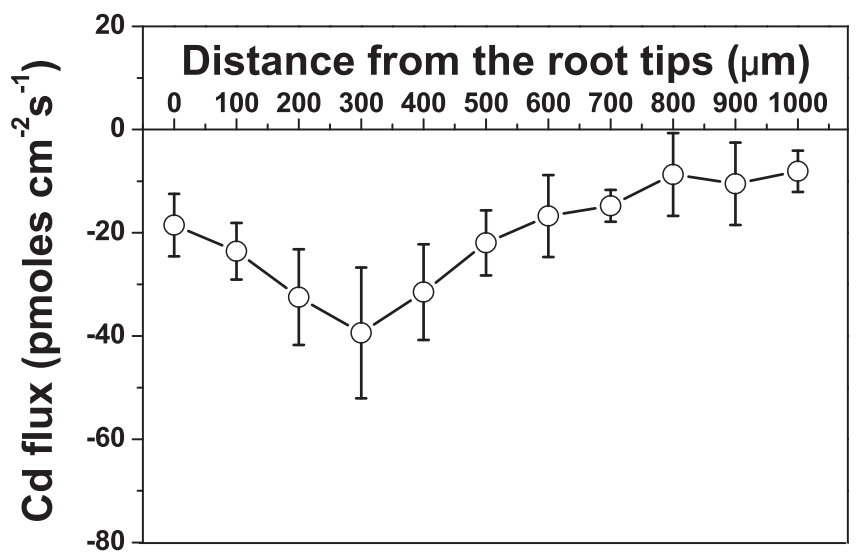

Fig. 1. Illustration of the magnitude of $\mathrm{Cd}^{2+}$ fluxes (mean \pm standard error) around root tips of wheat Triticum aestivum L.. Negative values indicate influx from solution to the root. Flux measurements were carried out in $10 \mu \mathrm{M} \mathrm{Cd}\left(\mathrm{NO}_{3}\right)_{2}$ at different positions along the root apex. Each point represents the mean of six seedlings and bars represent the standard error of the mean, measured at each position. Roots were scanned in segments of $100 \mu \mathrm{m}$ from the root tip. 
2.4. Net $\mathrm{Cd}^{2+}$ fluxes measurement at the root surface of Triticum aestivum $L$.

Net fluxes of $\mathrm{Cd}^{2+}$ at the surface of wheat roots were measured non-invasively with the application of scanning ion-selective electrode technique (BIO-001A; Younger USA, LLC, MA, USA), essentially as described by Shabala et al. (1997, 2001). Details on fabrication and calibration of $\mathrm{Cd}^{2+}$ ion selective microelectrodes have been described previously (Ma et al., 2010).

To monitor net fluxes of $\mathrm{Cd}^{2+}$ at different positions along the root apex of Triticum aestivum $\mathrm{L}$., an initial scanning measurement was carried out at the root tip followed by $100 \mu \mathrm{m}$ walk steps. With the plant intact, the primary (longest) root of each plant was selected and mounted horizontally in the measuring chamber, and loosely fixed in place with dental wax. The chamber was then filled with measuring solution consisting of $0.1 \mathrm{mM} \mathrm{Cd}\left(\mathrm{NO}_{3}\right)_{2}, 0.1 \mathrm{mM}$ $\mathrm{KCl}, 0.1 \mathrm{mM} \mathrm{CaCl}_{2}, 1.0 \mathrm{mM} \mathrm{NaCl}, 0.1 \mathrm{mM} \mathrm{MgSO}_{4}$, and $0.15 \mathrm{mM} 2-(\mathrm{N}-$
Morpholino) ethanesulfonic acid (MES) with pH of 6.0 and equilibrated for $10 \mathrm{~min}$. The equilibrated root was then used to record the net $\mathrm{Cd}^{2+}$ flux at each position in fresh measuring solution.

\subsection{Transient net $\mathrm{Cd}^{2+}$ fluxes at the root surface of Triticum aestivum $L$. with treatment of a metabolic inhibitor and $P C$ and protein synthesis inhibitor}

The transient $\mathrm{Cd}$ flux at the root position where the most intense Cd flux usually occurs was recorded before and after the treatment with the pharmaceuticals. The primary roots of seedlings were equilibrated in the measuring solution for $10 \mathrm{~min}$ and then a steady-state Cd flux was recorded using SIET for 10 min before the addition of pharmaceutical. A stock solution of the pharmaceutical selected was slowly added to the measuring solution to yield a final concentration that was the same as in the accumulation experiment describe above. Afterward, the measuring solution was

A

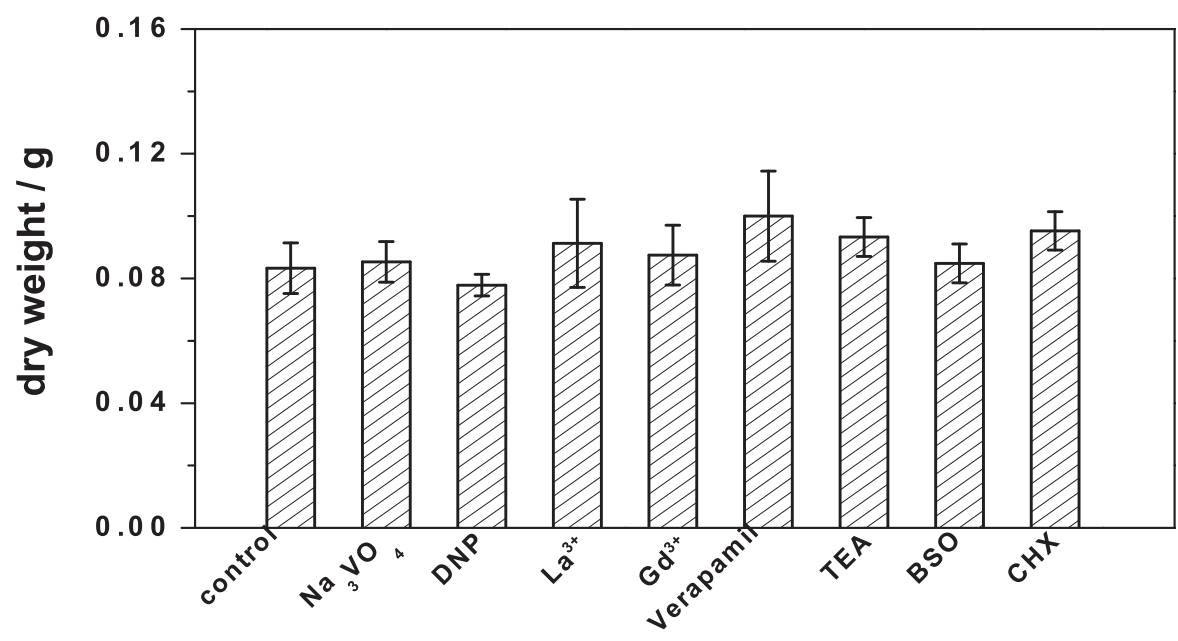

B

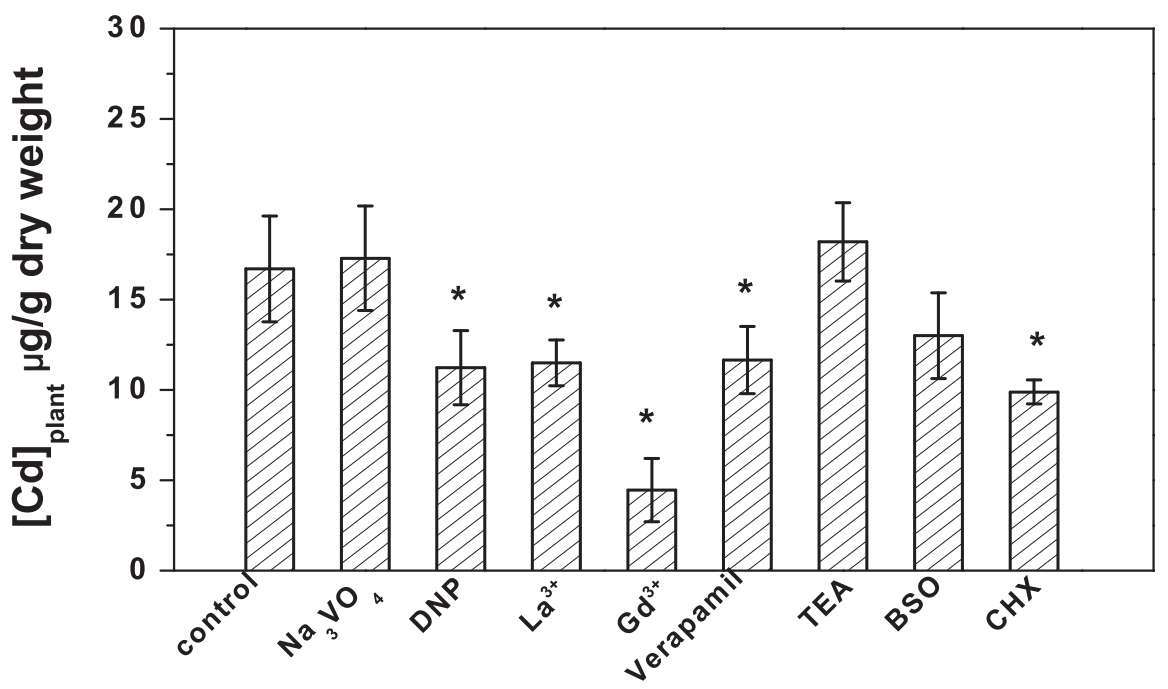

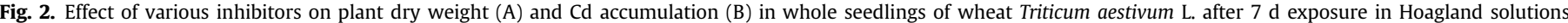

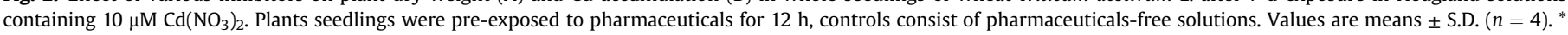
Indicates significant differences in metal accumulation from controls $(p<0.05)$. 
refreshed and the Cd flux recording was continued at the same position along the root as described above. For each treatment, at least six net $\mathrm{Cd}^{2+}$ flux measurements were made.

\subsection{Transient net $\mathrm{Cd}^{2+}$ fluxes at the root surface of Triticum} aestivum L. with treatment of ion channel blockers as well as in the presence of different level of inorganic cations

We determined the fluxes of $\mathrm{Cd}^{2+}$ at the root surface of wheat by treatment with a series of ion channel blockers: $\mathrm{La}^{3+}, \mathrm{Gd}^{3+}$ and Verapamil as well as TEA were used to modify the activity of $\mathrm{Ca}^{2+}$ and $\mathrm{K}^{+}$channels, respectively. The transient $\mathrm{Cd}$ flux at the root position where the most intense Cd flux usually occurs was recorded using SIET before and after the treatment with the pharmaceuticals as described above.

To further verify the possible effects of different ions on $\mathrm{Cd}$ uptake by Triticum aestivum $\mathrm{L}$., the real-time net $\mathrm{Cd}^{2+}$ fluxes were measured using SIET in measuring solution with $0.1,1.0$, and $10 \mathrm{mM}$ $\mathrm{Ca}^{2+}$ or $\mathrm{Mg}^{2+}$, as well as $2.5,5.0$, and $10.0 \mathrm{mM} \mathrm{Na}^{+}$or $\mathrm{K}^{+}$at the position where intense Cd flux usually occurs.

\subsection{Statistical analysis}

Data were analyzed by one-way Analysis of Variance (SPSS version 13.0 software for Windows). Data were shown as mean \pm standard error (S.E.M.). Duncan's Multiple Range test at the $5 \%$ level of probability was used to compare the differences in metal concentrations between treatments.

\section{Results}

As can be seen from Fig. 1, the $\mathrm{Cd}^{2+}$ flux profile showed a clear spatial organization and it was indicated that the highest $\mathrm{Cd}^{2+}$ influx was localized at positions $300 \mu \mathrm{m}$ from the root apex, with a steadily decreasing influx at all positions above and below this site.

To test whether the $\mathrm{H}^{+}$-ATPase plays a role in energizing $\mathrm{Cd}$ uptake, we used the P-type ATPase (including $\mathrm{H}^{+}$-ATPase) inhibitor $\mathrm{Na}_{3} \mathrm{VO}_{4}$ to inhibit $\mathrm{H}^{+}$-ATPase in the plant roots. The concentration of $\mathrm{Cd}$ in the whole plant was not affected by pre-treatment with $500 \mu \mathrm{M} \mathrm{Na}{ }_{3} \mathrm{VO}_{4}$ in solution $(P<0.05)$ (Fig. 2). The real time $\mathrm{Cd}^{2+}$ transport kinetics results showed that $\mathrm{Na}_{3} \mathrm{VO}_{4}$ did not inhibit the $\mathrm{Cd}$ uptake rate at the roots surface (Fig. 3). Treatment with $10 \mu \mathrm{M}$ 2,4-dinitrophenol (DNP), a metabolic inhibitor, resulted in considerable reduction of the $\mathrm{Cd}$ influx at the root at the same position of $300 \mu \mathrm{m}$ from the root apex (Fig. 3). Meanwhile, pre-treatment of wheat roots by DNP, caused the Cd contents of wheat to decrease by $33 \%$ (Fig. 2, $p<0.05$ ).

To further understand the pathways of Cd uptake and membrane transport in roots of wheat, we determined the Cd contents in wheat seedlings upon pretreatment with ion channel blockers and found that the $\mathrm{Ca}^{2+}$ channels blockers $\mathrm{La}^{3+}$ or $\mathrm{Gd}^{3+}$ as well as verapamil, at the whole-plant level, significantly decreased $\mathrm{Cd}$ levels $(p<0.05)$ (Fig. 2). Unlike the $\mathrm{Ca}^{2+}$ channel blocker, pretreatment with the $\mathrm{K}^{+}$channel blocker TEA had little effect on $\mathrm{Cd}$ uptake in plants $(p<0.05)$ (Fig. 2). In addition, the real-time net $\mathrm{Cd}^{2+}$ flux into root was reduced in SIET experiments with the treatments of $\mathrm{La}^{3+}$ or $\mathrm{Gd}^{3+}$ and Verapamil, but not in case of TEA (Fig. 4). These findings indicate that the uptake of $\mathrm{Cd}$ into the root of Triticum aestivum L. proceeds through channels permeable to $\mathrm{Ca}^{2+}$.

To further verify the $\mathrm{Cd}^{2+}$ membrane transport mechanism across the root of Triticum aestivum L., we investigated the effect of inorganic cations on the uptake and real-time kinetics of the Cd flux in the roots. The presence of Ca was found to significantly inhibit $\mathrm{Cd}$ uptake ( $p<0.05$, Fig. 5 ), reducing $\mathrm{Cd}$ concentration in the plants from $18.8 \mu \mathrm{g} \mathrm{g}^{-1}$ dry weight at $0.1 \mathrm{mM}$ Ca to $12.3 \mu \mathrm{g} \mathrm{g}^{-1}$ and
$8.4 \mu \mathrm{g} \mathrm{g}^{-1}$ dry weight at 1.0 and $10.0 \mathrm{mM} \mathrm{Ca}$, respectively (Fig. 5A). Similar to $\mathrm{Ca}$, increased $\mathrm{Mg}$ concentrations resulted in lower $\mathrm{Cd}$ contents (Fig. 5A). Our results also showed that Cd uptake by Triticum aestivum $\mathrm{L}$. was not reduced by increasing $\mathrm{K}^{+}$and $\mathrm{Na}^{+}$concentrations (Fig. 6A).

Addition of $1.0 \mathrm{mM}$ and $10.0 \mathrm{mM} \mathrm{Ca}^{2+}$ to the measuring solution significantly decreased the net $\mathrm{Cd}^{2+}$ influx in roots, reducing by $16 \%$ and $72 \%$ at $300 \mu \mathrm{m}$ back from the root apex, respectively (Fig. 5B, $\mathrm{p}<0.01$ ). However, when the $\mathrm{Mg}^{2+}$ concentration in the measuring solution was increased to $10.0 \mathrm{mM}$, the net $\mathrm{Cd}^{2+}$ flux into the root was changed from a net influx to a net efflux (Fig. 5B). The addition of $\mathrm{Na}^{+}$or $\mathrm{K}^{+}$in to the measuring solution had on the other hand no effect on the net $\mathrm{Cd}^{2+}$ flux at the root surface, even when the concentration of either $\mathrm{Na}^{+}$or $\mathrm{K}^{+}$in the measuring solution was increased to $10 \mathrm{mM}$ (Fig. 6B).

To further investigate whether the uptake and transport of $\mathrm{Cd}$ into the root of Triticum aestivum L. are related to PCs synthesis and protein synthesis, L-Buthionine-sulfoximine (BSO), a blocker of PC synthesis, and cycloheximide (CHX), a kind of protein synthesis inhibitor, were used in the present study. Pre-treatment with BSO had no effects on the Cd content in the whole plant $(p<0.05$, Fig. 2$)$ and the transient net $\mathrm{Cd}^{2+}$ fluxes at the roots surface were not changed significantly upon treatment with BSO (Fig. 7B). The mean of the net influx of $\mathrm{Cd}^{2+}$ was 47.0 pmol cm $\mathrm{cm}^{-2} \mathrm{~s}^{-1}$ and the $\mathrm{CHX}$ treatment decreased the net influx of $\mathrm{Cd}^{2+}$ to $20.8 \mathrm{pmol} \mathrm{cm}^{-2} \mathrm{~s}^{-1}$ at $300 \mu \mathrm{m}$ from the root apex (Fig. 7A). In addition, pre-treatment of CHX significantly inhibited Cd uptake in the whole plant $(p<0.05$, Fig. 2).

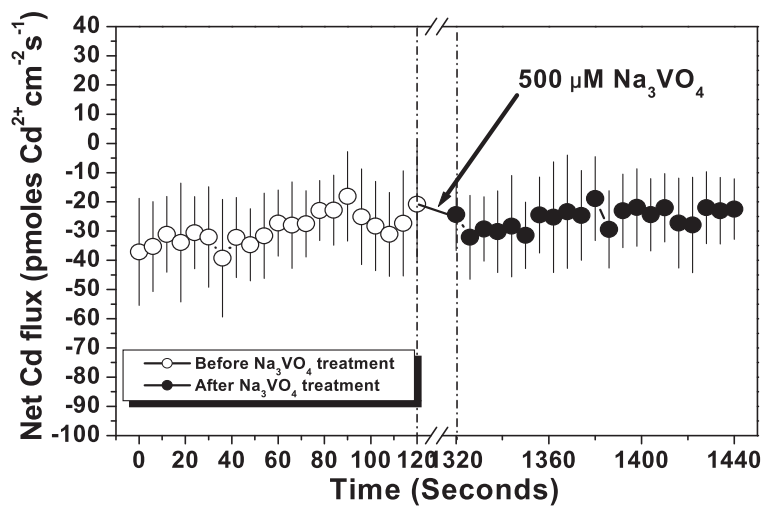

(A)

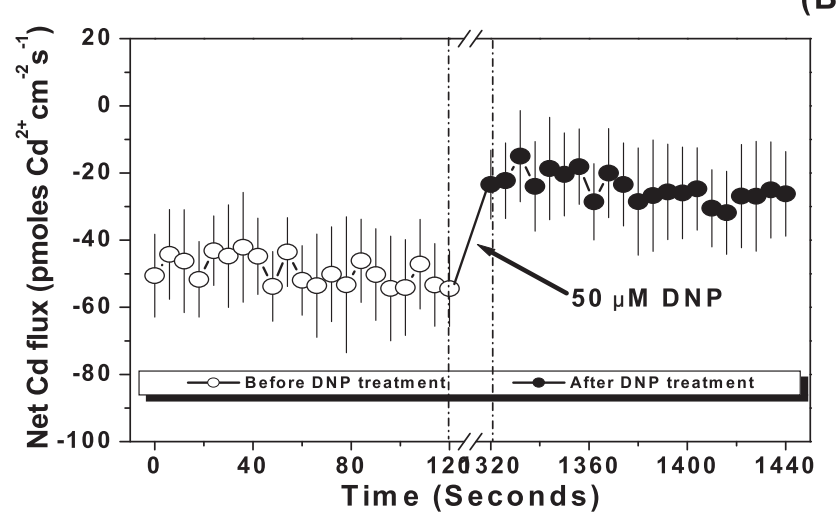

Fig. 3. Transient net $\mathrm{Cd}^{2+}$ flux at the root position $300 \mu \mathrm{m}$ from the root apex (where intense Cd flux usually occurs) of wheat Triticum aestivum L. before and after applications of $500 \mu \mathrm{M} \mathrm{Na} \mathrm{VO}_{4}$ (A) and $50 \mu \mathrm{M}$ dinitrophenol (DNP) (B). 


\section{Discussion}

\subsection{Localization of $\mathrm{Cd}^{2+}$ fluxes along the root apex of wheat}

The observed decrease of the net flux of $\mathrm{Cd}^{2+}$ at the root surface with increasing distance from the root tip is consistent with the research of Pineros et al. (1998). Pineros et al. (1998) found that the $\mathrm{Cd}^{2+}$ flux into the root of bread wheat was greatest in the region of about $0.6-1.2 \mathrm{~mm}$ from the root apex and decreased with increasing distance from the root apex. However, in our study, the most vigorous $\mathrm{Cd}^{2+}$ flux was observed in the apex region of $0-0.7 \mathrm{~mm}$ with a highest value at around $0.3 \mathrm{~mm}$ from the root tip (Fig. 1). These data indicate that the spatial patterns of the net $\mathrm{Cd}^{2+}$ flux along roots in these two studies are probably different between the wheat types or varieties. Farrell et al. (2005) have reported that there were differences in the net $\mathrm{Cd}^{2+}$ flux at the root surface of different wheat cultivars. This spatial difference in net $\mathrm{Cd}^{2+}$ flux may be attributed to differences in root anatomy (Dong et al., 1995) or localization of the $\mathrm{Cd}^{2+}$ uptake system (Page and Feller, 2005) between these wheat types or varieties. Although a similar $\mathrm{Cd}^{2+}$ flux pattern was also observed in the present study, the net $\mathrm{Cd}^{2+}$ flux was greater than that observed by Farrell et al. (2005) for durum wheat using the same $\mathrm{Cd}^{2+}$ selective microelectrode. Using ${ }^{109} \mathrm{Cd}$ radiotracer flux techniques, Hart et al. (1998) compared

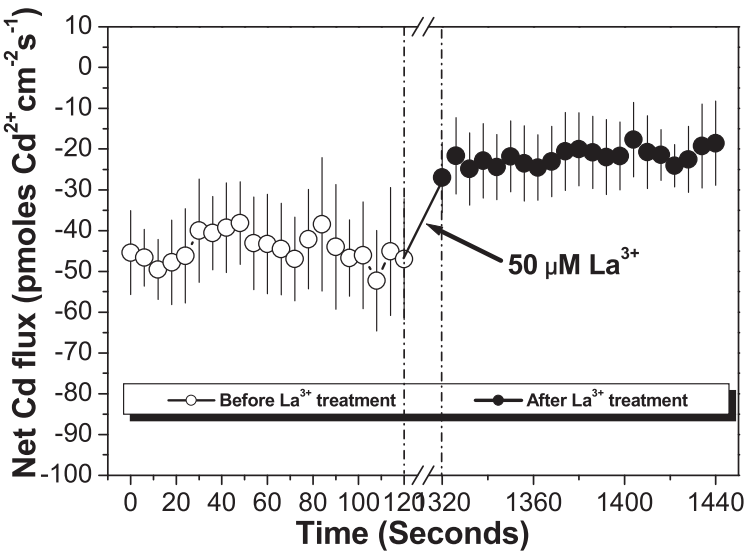

(C)

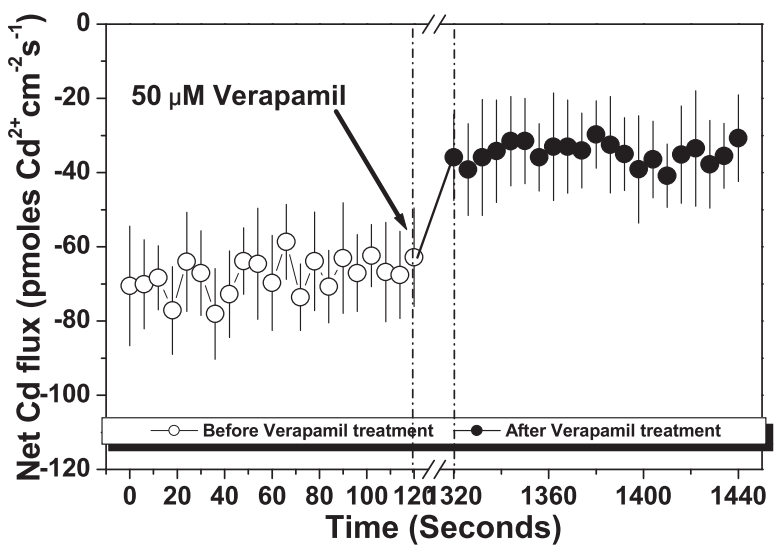

(A) uptake of $\mathrm{Cd}^{2+}$ in seedlings of bread and durum wheat cultivars and they found that the bread wheat cultivar had higher root $\mathrm{Cd}^{2+}$ uptake rates. Nevertheless, available evidences indicate that the grains $\mathrm{Cd}$ concentrations in durum wheat were higher as compared to that in bread wheat (Zook et al., 1970; Meyer et al., 1982). These results suggested that the high $\mathrm{Cd}$-accumulation in grain of durum wheat could not be solely attributed to high $\mathrm{Cd}$ influxes at the root surface.

4.2. The effect of metabolic inhibitors on Cd uptake and real-time kinetics transport at the root of Triticum aestivum $L$.

All membranes P-type ATPase could be inhibited by $\mathrm{Na}_{3} \mathrm{VO}_{4}$. Pre-treatment of wheat roots by $\mathrm{Na}_{3} \mathrm{VO}_{4}$ did not significantly inhibit Cd uptake in our study (Fig. 2), suggesting that Cd uptake into the root of wheat was not dependent upon physiological functions of the plasma membrane P-type ATPase.

As an uncoupler of oxidative phosphorylation, DNP has the ability to break down proton gradients by increasing proton permeability of biomembranes leading to inhibition of ATP biosynthesis (Felle and Bentrup, 1977; Tripathi et al., 1995). The significant suppression of the Cd influx by the metabolic inhibitor DNP suggests the existence of metabolic mediation in the $\mathrm{Cd}^{2+}$ uptake process by wheat. Cd entry into the root involves a

(B)

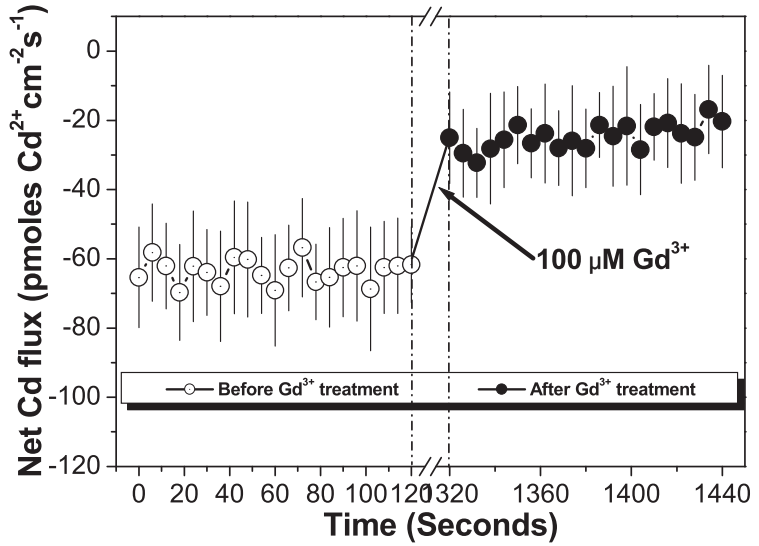

(D)

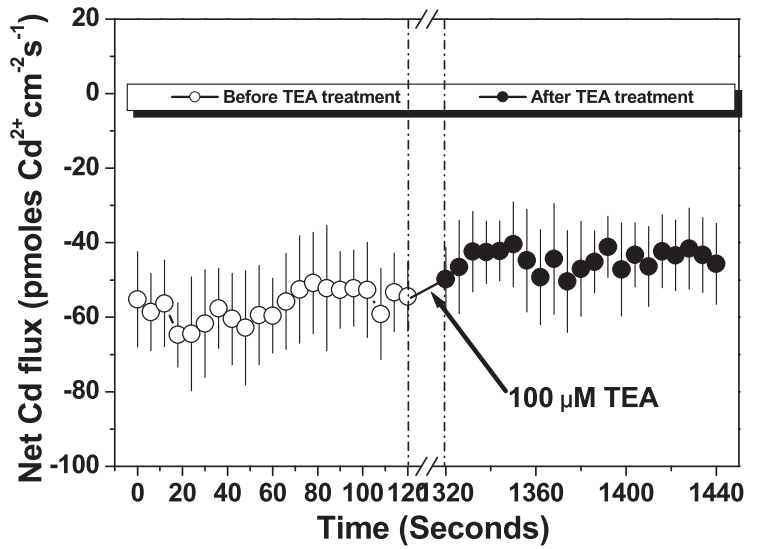

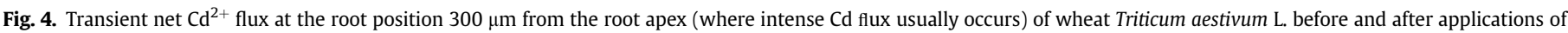
$50 \mu \mathrm{M} \mathrm{La}^{3+}$ (A), $100 \mu \mathrm{M} \mathrm{Gd}^{3+}$ (B), $50 \mu \mathrm{M}$ Verapamil (C) and $100 \mu \mathrm{M}$ tetraethylammonium (TEA) (D). 
symplastic pathway that is dependent on metabolic energy. Many studies have shown that inhibition of metabolism affects the uptake of $\mathrm{Cd}$, in which the symplastic pathway rather than the apoplastic pathway is believed to play an important role. The observation of inhibition of Cd uptake by the metabolic inhibitor DNP led to the conclusion that the metabolism plays an important role in the movement of $\mathrm{Cd}^{2+}$ into the root cells of soybean (Glycine max) (Cataldo et al., 1983). Similarly, most of the Cd translocated from roots to the shoot in 'high' isolines of durum wheat probably via the symplastic pathway (Van der Vliet et al., 2007; Quinn et al., 2011).

\subsection{The effect of ion channel blockers on Cd uptake and real-time kinetics transport at the root of Triticum aestivum $L$.}

To test the potential effect of $\mathrm{Ca}^{2+}$ permeable channels on $\mathrm{Cd}$ uptake, the Cd content was measured in wheat seedlings pretreated with $\mathrm{Ca}^{2+}$ channel blockers. Our experiments with inorganic channel blockers showed that $\mathrm{Cd}$ accumulation was strongly inhibited by $\mathrm{La}^{3+}$ and $\mathrm{Gd}^{3+}$, as well as by the organic $\mathrm{Ca}^{2+}$ channel blocker verapamil (Fig. 2). The results of Clemens et al. (1998) also showed that the $\mathrm{Cd}^{2+}$ uptake activity of the transporter LTC1 in wheat was blocked by $\mathrm{La}^{3+}$ and $\mathrm{Ca}^{2+}$. Nevertheless, the $\mathrm{K}^{+}$channel blocker TEA did not suppress the Cd uptake (Fig. 2, $p<0.05$ ). In addition, the $\mathrm{Cd}$ content in plant seedlings decreased with increasing $\mathrm{Ca}^{2+}$ and $\mathrm{Mg}^{2+}$ concentrations, but not in the presence of different concentrations of $\mathrm{Na}^{+}$and $\mathrm{K}^{+}$(Figs. 6 and 7). Thus, $\mathrm{Cd}^{2+}$ is likely taken up by wheat through channels permeable to $\mathrm{Ca}^{2+}$, as confirmed by the results showing reduced real-time net $\mathrm{Cd}^{2+}$ fluxes at the root surface upon treatment with $\mathrm{Ca}^{2+}$ channel blockers, as well as in the presence of high concentrations of $\mathrm{Ca}^{2+}$ (Fig. 6). In other report, it was found that $\mathrm{Cd}$ could enter guard cell protoplasts via $\mathrm{Ca}^{2+}$ channels, but not by $\mathrm{K}^{+}$channels (Perfus-Barbeoch et al., 2002). The results of Lindberg et al. (2004) also showed that Cd uptake into the cytosol of wheat protoplasts partly takes place by channels permeable to $\mathrm{Ca}^{2+}$. These results supported our finding that the uptake of $\mathrm{Cd}^{2+}$ by wheat (Triticum aestivum L.) is mediated at least in part by $\mathrm{Ca}^{2+}$ channels. By measuring the real-time kinetics of Cd transport using SIET, we herein provided direct evidence of the regulation of $\mathrm{Cd}^{2+}$ uptake by $\mathrm{Ca}^{2+}$ transporters in root cell plasma membranes of bread wheat.

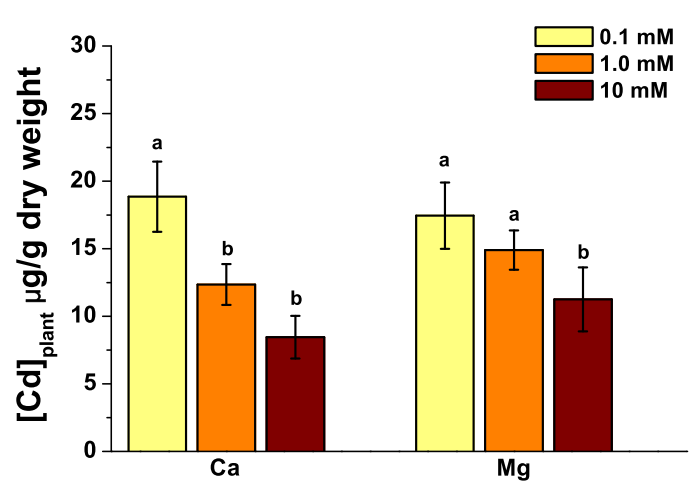

(A)

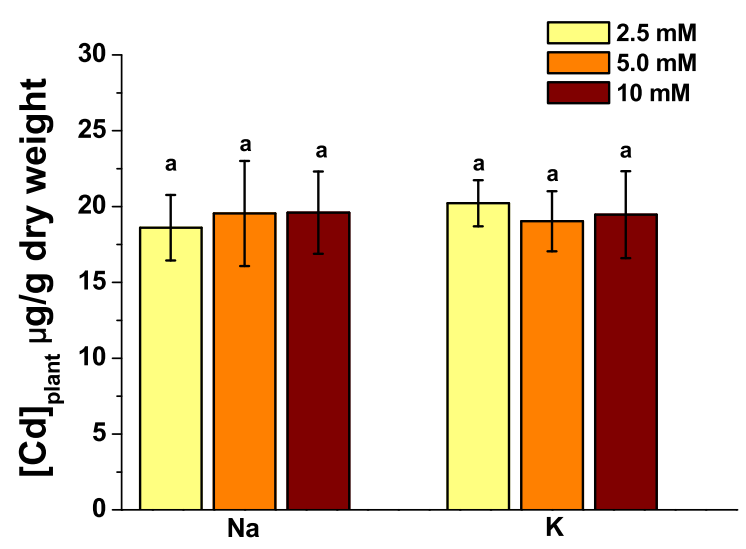

(A)

(B)
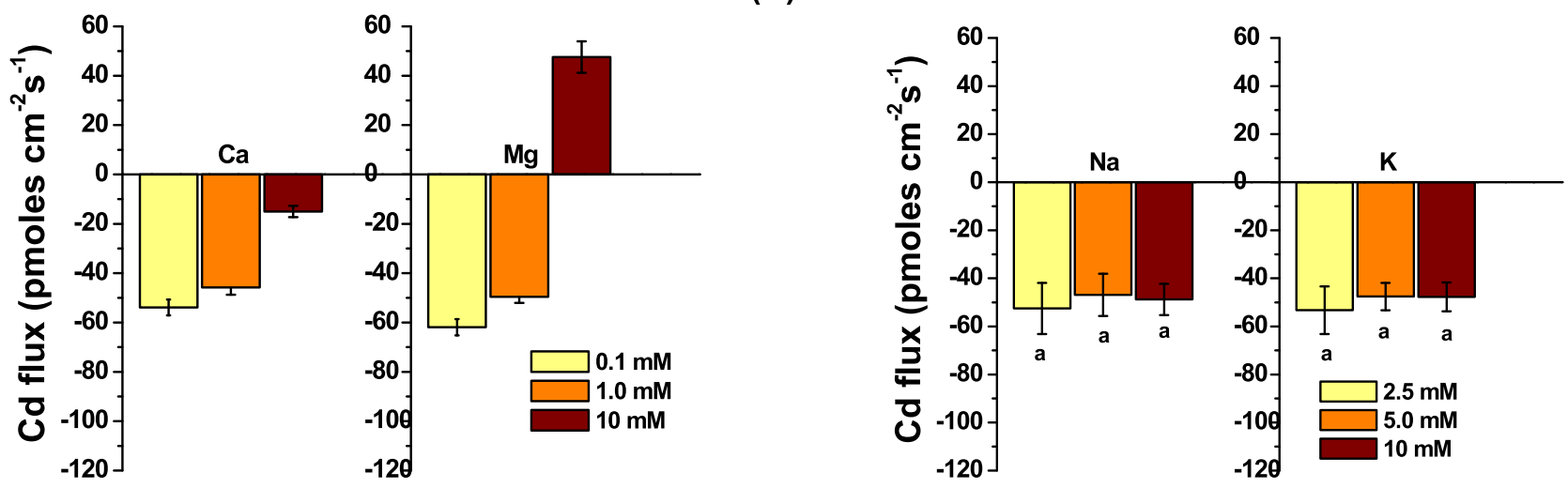

(B)

Fig. 5. Cd uptake and real-time net $\mathrm{Cd}$ fluxes on the root of wheat Triticum aestivum $\mathrm{L}$. in the presence of different concentration of Ca or Mg. (A) In the uptake experiment, the Hoagland solution containing $10 \mu \mathrm{M} \mathrm{Cd}$ was used as the background nutrient solution. Values are means \pm S.D. $(n=4)$. Bars with different letters are significantly different $(p<0.05)$. (B) Mean rates of Cd fluxes during record in the different concentrations of $\mathrm{Ca}$ or $\mathrm{Mg}$. Columns labeled with different letters are significantly different $(p<0.05)$. The net $\mathrm{Cd}^{2+}$ fluxes were measured at the position $300 \mu \mathrm{m}$ (where intense Cd flux usually occurs) back from the root apex.

Fig. 6. Cd uptake and real-time net $\mathrm{Cd}$ fluxes on the root of wheat Triticum aestivum $\mathrm{L}$. in the presence of different concentration of Na or K. (A) In the uptake experiment, the Hoagland solution containing $10 \mu \mathrm{M} \mathrm{Cd}$ was used as the background nutrient solution. Values are means \pm S.D. $(n=4)$. Bars with different letters are significantly different $(p<0.05)$. (B) Each column represents the mean of four individual plants. The bars represent the standard error of the mean. Columns labeled with different letters are significantly different $(p<0.05)$. The net $\mathrm{Cd}^{2+}$ fluxes were measured at the position $300 \mu \mathrm{m}$ (where intense Cd flux usually occurs) back from the root apex. 
4.4. Effect of phytochelatin $(P C)$ and protein synthesis inhibitors on $C d$ uptake and real-time kinetics transport at the root of Triticum aestivum $L$.

The role of PCs in Cd tolerance has been well characterized in various plants and other living organisms (Zenk, 1996; Cobbett, 2000), but the role of PCs in uptake of Cd is still unclear. In the present study, the potential role of PCs synthesis on Cd uptake by Triticum aestivum L. was evaluated by blocking PCs production via $\mathrm{L}-$ Buthionine-sulfoximine (BSO). Pre-treatment of BSO had no effects on the $\mathrm{Cd}$ content in the plants $(p<0.05)$ (Fig. 2), which is confirmed by the fact that treatment with BSO did not reduce the real-time net $\mathrm{Cd}$ fluxes at the root surface as deduced using SIET (Fig. 7A). The results obtained suggested that PC synthesis bears no relationship to the uptake of $\mathrm{Cd}^{2+}$ into wheat roots. On the other hand, the results from Lindberg et al. (2004) indicated that pretreatment with $\mathrm{Cd}^{2+}$ (with increased PCs content) decreased the short-term uptake of $\mathrm{Cd}^{2+}$ into the cytosol of wheat protoplasts. In other report, it was also found that accumulation of Cd after $24 \mathrm{~h}$ increased in yeast cells transformed with a PCS1 gene (phytochelatin synthase 1 gene) from wheat (Clemens et al., 1998). To further investigate whether the transport of $\mathrm{Cd}$ into the root of wheat takes place via specific transport proteins, the root was treated with a typical protein synthesis inhibitor CHX (Seo et al., 2009). Upon CHX treatment, the $\mathrm{Cd}^{2+}$ uptake and influxes in the roots decreased significantly, indicating that specific transport proteins are involved in $\mathrm{Cd}^{2+}$ uptake by wheat. Thus, except for the ion channels (White, 1996), ion pumping and carriers might be involved in the passage of ions through the plasma membranes of wheat. Further biochemical and molecular studies are required to identify and document the role of ion channels and specific transport proteins in $\mathrm{Cd}^{2+}$ uptake and transport on the root of Triticum aestivum L.. All the concentrations of the pharmaceuticals used in this study were selected based on previous literature reports showing that these concentrations are physiologically relevant (Tripathi et al., 1995; White, 1996; Zhang et al., 2012). In our experiment the seedlings showed no obvious plant toxicity symptoms and the mean weight of individual plants was comparable among the different treatments (Fig. 2A). It is reasonable to propose that the differences in $\mathrm{Cd}$ absorption among different treatments

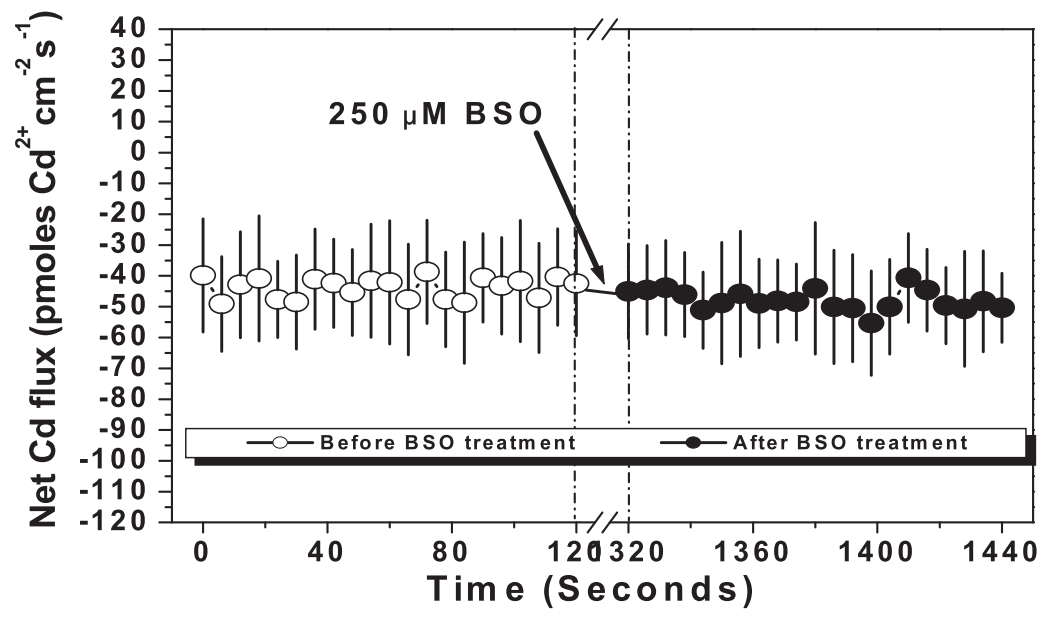

(A)

(B)

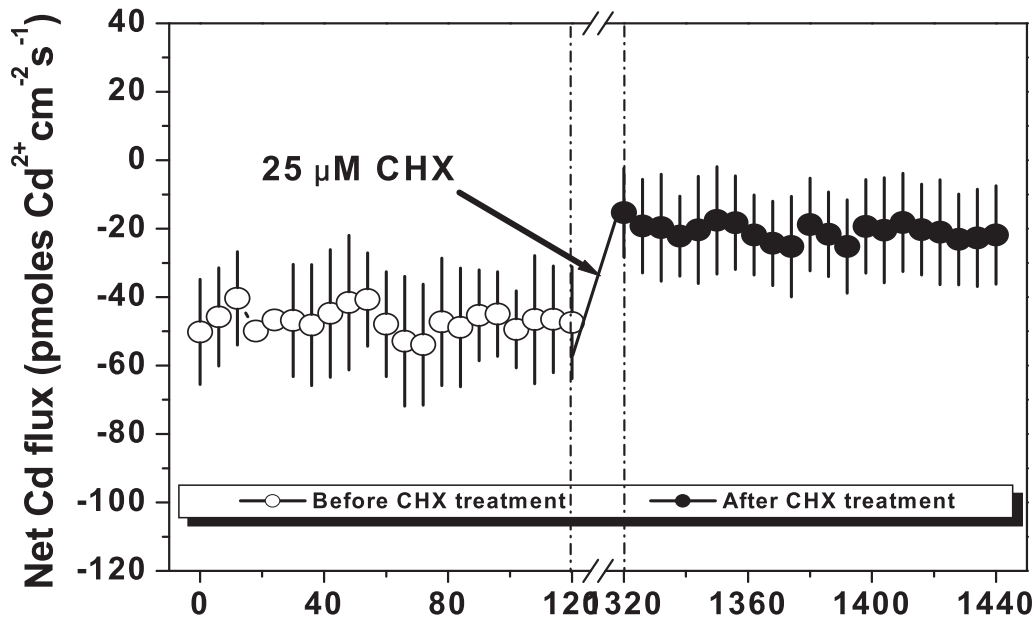

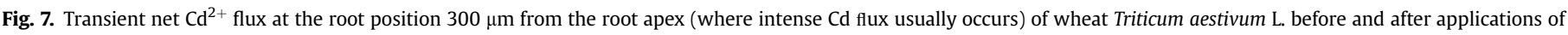
$250 \mu \mathrm{M}$ L-Buthionine-sulfoximine (BSO) (A) and $25 \mu \mathrm{M}$ cycloheximide (CHX) (B). 
may be attributed to the direct effect of various pharmaceuticals. In summary, uptake and the real-time kinetics transport of $\mathrm{Cd}^{2+}$ in roots of Triticum aestivum L. was significantly suppressed by metabolic inhibitors, which demonstrated that uptake of $\mathrm{Cd}^{2+}$ by roots of Triticum aestivum $\mathrm{L}$. depends on metabolic energy. $\mathrm{Ca}^{2+}$ channel blockers as well as high concentrations of $\mathrm{Ca}^{2+}$ decreased $\mathrm{Cd}$ uptake and the real-time net $\mathrm{Cd}^{2+}$ fluxes at the root surface, indicating that uptake of $\mathrm{Cd}^{2+}$ by Triticum aestivum $\mathrm{L}$. is related to $\mathrm{Ca}^{2+}$ channels. In addition, our results suggest a role of protein synthesis in mediating $\mathrm{Cd}^{2+}$ uptake by Triticum aestivum L.. Inhibition of $\mathrm{Cd}^{2+}$ uptake by selected pharmaceuticals and inorganic cations was confirmed by direct evidence of assessment of real time $\mathrm{Cd}^{2+}$ fluxes at the root surface, as performed using SIET. These findings are helpful for us to understand the $\mathrm{Cd}^{2+}$ uptake pathways and the physiological processes that result in excess Cd accumulation in wheat.

\section{Acknowledgements}

This study is supported by the National Natural Science Foundation (No. Y311111031 and 41230858). We also want to thank Dr. Rob Reid from University of Adelaide for his constructive comments in the improvement of the manuscript.

\section{References}

Australia New Zealand, 2013. Standard 1.4.1 Contaminants and Natural Toxicants. Cataldo, D.A., Garland, T.R., Wildung, R.E., 1983. Cadmium uptake kinetics in intact soybean plants. Plant Physiol. 73, 844-848.

Clemens, S., Antosievicz, D.M., Ward, J.M., Schachtman, D.P., Schroeder, J.I., 1998. The plant cDNA LCT1 mediates the uptake of calcium and cadmium in yeast. P. Nati. Acad. Sci. U. S. A. 95, 12043-12048.

Cobbett, C.S., 2000. Phytochelatins and their roles in heavy metal detoxification. Plant Physiol. 123, 825-832.

Cohen, C.K., Fox, T.C., Garvin, D.F., Kochian, L.V., 1998. The role of iron defenciency stress responses in stimulating heavy metal transport in plants. Plant Physiol. 116, 1063-1072.

Connolly, E.L., Fett, J.P., Guerinot, M.L., 2002. Expression of the IRT1 metal transporter is controlled by metals at the levels of transcript and protein accumulation. Plant Cell 14, 1347-1357.

Dong, B., Rengel, Z., Graham, R.D., 1995. Root morphology of wheat genotypes differing in zinc efficiency. J. Plant Nutr. 18, 2761-2773.

European Commission, 2001. Commission Regulation (EC) no. 466/2001 of 8 March 2001 setting maximum levels for certain contaminants in foodstuffs. Off. J. Eur. Communities Legis 77, 1-13.

Farrell, R.E., McArthur, D.F.E., Van Rees, K.C.J., 2005. Net $\mathrm{Cd}^{2+}$ flux at the root surface of durum wheat (Triticum turgidum L. var. durum) cultivars in relation to cultivar differences in Cd accumulation. Can. J. Plant Sci. 85, 103-107.

Felle, H., Bentrup, F.W., 1977. A study of the primary effect of the uncoupler carbonyl cyanide m-chlorophenylhydrazone on membrane potential and conductance in Riccia fluitens. Biochim. Biophys. Acta 464, 179-187.

Food and Agriculture Organization/World Health Organization, 2001. Comments Submitted on the Draft Guideline Level and Proposed Draft Maximum Levels for Cadmium. Joint FAO/WHO Food Standards Programme. Codex Alimentarius Commission (thirty-third sessions).

GB 2762, 2012. National Food Safety Standards for Maximum Levels of Contaminants in Foods [S].

Hart, J.J., Welch, R.M., Norvell, W.A., Sullivan, L.A., Kochian, L.V., 1998. Characterization of cadmium binding, uptake, and translocation in intact seedlings of bread and durum wheat cultivars. Plant Physiol. 116, 1413-1420.

Ismail, M.A., 2008. Involvement of $\mathrm{Ca}^{2+}$ in alleviation of $\mathrm{Cd}^{2+}$ toxicity in common bean (Phaseolas vulgaris L.). Asian. J. Biol. Sci. 1, 26-32.

Kinraide, T., 1998. Three mechanisms for the calcium alleviation ofmineral toxicities. Plant Physiol. 118, 513-520.

Kochian, L.V., Shaff, J.E., Kuhtreiber, W.M., Jaffe, L.F., Lucas, W.J., 1992. Use of an extracellular ionselective vibrating microelectrode system for the quantification of $\mathrm{K}^{+}, \mathrm{H}^{+}$and $\mathrm{Ca}^{2+}$ fluxes in maize roots and maize suspension cells. Planta 188, 601-610.

Lindberg, S., Landberg, T., Greger, M., 2004. A new method to detect cadmium uptake in protoplasts. Planta 219, 526-532.

Liu, Y., Vijver, M.G., Peijnenburg, W.J.G.M., 2014. Impacts of major cations ( $\mathrm{K}^{+}, \mathrm{Na}^{+}$, $\mathrm{Ca}^{2+}, \mathrm{Mg}^{2+}$ ) and protons on toxicity predictions of nickel and cadmium to lettuce (Lactuca sativa L.) using exposure models. Ecotoxicology 23, 385-395. Ma, W.W., Xu, W.Z. Xu, H., Chen, Y.S., He, Z.Y., Ma, M., 2010. Nitric oxide modulates cadmium influx during cadmium-induced programmed cell death in tobacco BY-2 cells. Planta 232, 325-335.

Meyer, M.W., Fricke, F.L., Holmgren, G.G.S., Kubota, J., Chaney, R.L., 1982. Cadmium and lead in wheat grain and associated surface soils of major wheat production areas of the United States. In: Agronomy Abstracts. The American Society of Agronomy, Madison, WI, p. 34.

Newman, I.A., Kochian, L.V., Grusak, M.A., Lucas, W.J., 1987. Fluxes of $\mathrm{H}^{+}$and $\mathrm{K}^{+}$in corn roots. Characterization and stoichiometries using ion-selective microelectrodes. Plant Physiol. 84, 1177-1184.

Newman, I.A., 2001. Ion transport in roots: measurement of fluxes using ionselective microelectrodes to characterize transporter function. Plant Cell Environ. 24, 1-14.

Page, V., Feller, U., 2005. Selective transport of zinc, manganese, nickel, cobalt and cadmium in the root system and transfer to the leaves in young wheat plants. Ann. Bot. 96, 425-434.

Pang, J.Y., Newman, I., Mendham, N., Zhou, M., Shabala, S., 2006. Microelectrode ion and $\mathrm{O}_{2}$ fluxes measurements reveal differential sensitivity of barley root tissues to hypoxia. Plant Cell Environ. 29, 1107-1121.

Pence, N.S., Larsen, P.B., Ebbs, S.D., Letham, D.L.D., Lasat, M.M., Garvin, D.F., Eide, D. Kochian, L.V., 2000. The molecular physiology of heavy metal transport in the Zn/Cd hyperaccumulator Thlaspi caerules-cens. P. Nati. Acad. Sci. U. S. A. 97, 4956-4960.

Perfus-Barbeoch, L., Leonhardt, N., Vavasseur, A., Forestier, C., 2002. Heavy metal toxicity: cadmium permeates through calcium channels and disturbs the plant water status. Plant J. 32, 539-548.

Pineros, M.A., Shav, J.E., Kochian, V., 1998. Development, characterization, and application of a cadmium-selective microelectrode for the measurement of cadmium fluxes in roots of Thlaspi species and wheat. Plant Physiol. 116, 1393-1401.

Puschenreiter, M., Horak, O., Friesl, W., Hartl, W., 2005. Low-cost agricultura measures to reduce heavy metal transfer into the food chain-a review. Plant Soil Environ. 51, 1-11.

Quinn, C.J., Mohammad, A., Macfie, S.M., 2011. Accumulation of cadmium in nearisogenic lines of durum wheat (Triticum turgidum L. var durum): the role of transpiration. Physiol. Mol. Biol. Plants 17, 317-325.

Seo, S.G., Kang, S.W., Shim, I.S., Kim, W., Fujihara, S., 2009. Effects of various chemical agents and early ethylene production on floral senescence of Hibiscus syriacus L. Plant Growth Regul. 57, 251-258.

Shabala, S., Newman, I.A., Morris, J., 1997. Oscillations in $\mathrm{H}^{+}$and $\mathrm{Ca}^{2+}$ ion fluxes around the elongation region of corn roots and effects of external $\mathrm{pH}$. Plant Physiol. 113, 111-118.

Shabala, L., Ross, T., Newman, I., McMeekin, T., Shabala, S., 2001. Measurements of net fluxes and extracellular changes of $\mathrm{H}^{+}, \mathrm{Ca}^{2+}, \mathrm{K}^{+}$and $\mathrm{NH}_{4}^{+}$in Escherichia coli using ion-selective microelectrodes. J. Microbiol. Methods 46, 119-129.

Smith, P.J.S., Sanger, R.H., Jaffe, L.F., 1994. The vibrating $\mathrm{Ca}^{2+}$ electrode: a new technique for detecting plasma membrane regions of $\mathrm{Ca}^{2+}$ influx and efflux. Methods Cell Biol. 40, 115-134.

Suzuki, N., 2005. Alleviation by calcium of cadmium-induced root growth inhibition in Arabidopsis seedlings. Plant Biotechnol. 22, 19-25.

Tripathi, R.D., Rai, U.N., Gupta, M., Yunus, M., Chandra, P., 1995. Cadmium transport in submerged macrophyte Ceratophyllum demersum L. in presence of various metabolic inhibitors and calcium channel blockers. Chemosphere 31, 3783-3791.

Van der Vliet, L., Peterson, C., Hale, B., 2007. Cd accumulation in roots and shoots of durum wheat: the roles of transpiration rate and apoplastic bypass. J. Exp. Bot 58, 2939-2947.

White, P.J., 1996. Specificity of ion channel inhibitors for the maxi cation channel in rye root plasma membranes. J. Exp. Bot. 47, 713-716.

Yang, C.M., Juang, K.W., 2015. Alleviation effects of calcium and potassium on cadmium rhizotoxicity and absorption by soybean and wheat roots. J. Plant Nutr. Soil Sci. 178, 748-754.

Zeng, X., Ma, L.Q., Qiu, R., Tang, Y., 2009. Responses of non-protein thiols to Cd exposure in Cd hyperaccumulator Arabis paniculata Franch. Environ. Exp. Bot. $66,242-248$

Zenk, M.H., 1996. Heavy metal detoxification in higher plants: a review. Gene 179 $21-30$.

Zhang, Y., Tai, P., Li, P., Liu, W., Yin, W., Zhao, O., Dong, D., 2012. Cadmium accumulation of Tagetes erecta L. Affected by plant growth inhibitors and glutathione. J. Plant Nutr. 35, 1053-1064.

Zook, E.G., Greene, F.E., Morris, E.R., 1970. Nutrient composition of selected wheats and wheat products. VI. Distribution of manganese, copper, nickel, zinc, magnesium, lead, tin, cadmium, chromium, and selenium as determined by atomic absorption spectroscopy and colorimetry. Cereal Chem. 47, 720-731.

Zorrig, W., Shahzad, Z., Abdelly, C., Berthomieu, P., 2012. Calcium enhances cadmium tolerance and decreases cadmium accumulation in lettuce (Lactuca sativa). Afr. J. Biotechnol. 11, 8441-8448. 